\title{
ANALISIS PERUMUSAN REKOMENDASI TIM ASSESMEN TERPADU DAN PENERIMAAN HAKIM BNN PROVINSI SUMATERA BARAT
}

\author{
Marryo Borry WD ${ }^{1}$, Hardisman ${ }^{2}$, Rika Susanti ${ }^{3}$ \\ 1,2,3 Fakultas Kedokteran Universitas Andalas Padang
}

Submitted: 19-12-2019, Reviewer: 25-12-2019, Accepted: 30-12-2019

\begin{abstract}
Abstrak
Penanganan tersangka penyalahguna narkotika masih menjadi permasalahan. Pemerintah mencoba membuat peraturan bersama yaitu membuat Tim Asesemen Terpadu dengan Badan Narkotika Nasional sebagai leading sector. Badan Narkotika Nasional Provinsi Sumatera Barat sejak tahun 2015 sampai dengan tahun 2018 telah melaksanakan Asesmen terpadu. Dari 181 tersangka di berikan rekomendasi, 80 rekomendasi tidak di terima hakim. Tujuan dari penelitian ini yaitu untuk mengalisis faktor-faktor yang berperan dalam Penyebab Tidak di Terimanya Rekomendasi Tim Asesmen Terpadu Badan Narkotika Nasional Provinsi Sumatera Barat. Penelitian ini merupakan jenis penelitian kualitatif. Penelitian ini digunakan metode Framework Analysis. Objek dalam penelitian kualitatif adalah rekomendasi tim asesmen terpadu. Hasil penelitian ini pada sumber daya manusia didapatkan komposisi tim dokter belum terpenuhi, hakim kurang mengerti tentang proses asesmen terpadu. Pada sarana dan prasarana SOP yang masih belum terstruktur dan belum ada alat pemeriksaan tambahan. Pada proses pemeriksaan dilakukan kurang lengkap karena waktu pemeriksaan singkat, dan belum optimalnya monitoring.
\end{abstract}

Kata kunci: Asesmen Terpadu, Rekomendasi

\begin{abstract}
The handling of narcotics abuse suspects is still a problem. The government is trying to make a joint regulation that is making an Integrated Assessment Team with the National Narcotics Board as a leading sector. The National Narcotics Board of West Sumatra Province from 2015 to 2018 has implemented an integrated assessment. Of the 181 suspects given recommendations, 80 recommendations were not received by the judge. The purpose of this study is to analyze the factors that play a role in the Causes of Not Accepting Recommendations of the Integrated Assessment Team of the National Narcotics Board of West Sumatra Province. This research is a type of qualitative research. This research used Framework Analysis method. The object in qualitative research is the recommendation of the integrated assessment team. The results of this study on human resources obtained the composition of the team of doctors has not been fulfilled, the judge did not understand about the integrated assessment process. The SOP facilities and infrastructure are still not structured and there are no additional inspection tools. In the inspection process is done incomplete because of the short inspection time, and monitoring is not yet optimal.
\end{abstract}

Keywords: Integrated Assessment, Recommendations 


\section{PENDAHULUAN}

Penyalahgunaan dan peredaran gelap narkotika menjadi isu yang strategis bagi masyarakat dunia. Kejahatan narkotika merupakan kejahatan serius, terorganisir dan bersifat lintas negara yang dapat menimpa seluruh lapisan masyarakat sehingga menimbulkan kerugian sangat besar, terutama dari segi kesehatan, sosial-ekonomi dan keamanan. Fatalnya, kejahatan ini dapat menyebabkan hilangnya generasi bangsa (lost generation), cikal bakal penerus pembangunan. Masyarakat dunia tak henti-hentinya melakukan berbagai upaya untuk mencegah penyalahgunaan dan memberantas peredaran gelap narkotika. Kebijakan dan program guna membersihkan dunia dari candu narkotika juga telah disepakati bersama dalam forum pertemuan yang digagas oleh UNODC (United Nations Office On Drugs Crime), namun ancaman narkotika tidak dapat sepenuhnya teratasi, bahkan kian menjadi pelik bagi negaranegara di dunia (Martono, 2006)

Survei yang dilakukan oleh Badan Narkotika Nasional bekerjasama dengan Pusat Penelitian Kesehatan Universitas Indonesia pada tahun 2014 menunjukkan bahwa estimasi penyalahguna NAPZA adalah sekitar 2,18\% dari total seluruh penduduk Indonesia berusia 10- 59 tahun. Pada tahun 2016 diproyeksikan angka prevalensi sebesr $2,21 \%$ atau setara dengan 4.173.633 orang. Dari sejumlah penyalahguna tersebut, terdistribusi atas $0,87 \%$ coba pakai, $0,82 \%$ teratur pakai, $0,49 \%$ pecandu bukan suntik, dan $0,04 \%$ pecandu suntik.. Berdasarkan survei BNN tahun 2016 di kalangan pelajar dan mahasiswa diketahui, hampir semua (91\%) pelajar dan mahasiswa pernah mendengar jenis narkoba di tahun 2016, dengan proporsi terendah pada kelompok SMP (88\%) (BNN, 2018). Mahkamah Agung RI menyadari bahwa sebagian besar dari narapidana dan tahanan kasus narkoba adaah termasuk kategori pemakai atau bahkan sebagai korban yang jika dilihat dari aspek kesehatan, mereka sesungguhnya orang-orang yang menderita sakit. Oleh karena itu, memenjarakan para pemakai atau korban penyalahgunaan narkoba bukanlah sebuah langkah yang tepat karena telah mengabaikan kepentingan perawatan dan pengobatan. Kondisi Lembaga Pemasyarakatan (LAPAS) yang tidak mendukung dampak negatif keterpengaruhan oleh perilaku kriminal lainnya dapat semakin memperburuk kondisi kejiwaan dan kesehatan yang diderita para narapidana narkotika dan psikotropika (Catio, 2006)

Berdasarkan Pasal 47 UndangUndang Nomor 22 Tahun 1997 tentang Narkotika, mengatur bahwa hakim yang memeriksa perkara pecandu narkotika dapat memutuskan untuk memerintahkan yang bersangkutan menjalani pengobatan dan/atau perawatan, apabila pecandu narkotika tersebut terbukti melakukan tindak pidana narkotika, atau menetapkan untuk memerintahkan yang bersangkutan menjalani pengobatan dan/atau perawatan apabila pecandu narkotika tersebut tidak terbukti bersalah melakukan tindak pidana narkotika. Berdasarkan pemaparan di atas, maka muncul alternatif penjatuhan sanksi lain dalam upaya pencegahan dan pemberantasan peredaran gelap narkotika agar dapat berjalan lebih efektif, yaitu penjatuhan sanksi 
tindakan berupa rehabilitasi. (Undang-Undang Nomor 22, 1997)

Berdasarkan Pasal 127 ayat (3) Undang-Undang Nomor 35 Tahun 2009 tentang Narkotika diatur, "dalam hal Penyalah Guna sebagaimana dimaksud pada ayat (1) dapat dibuktikan atau terbukti sebagai korban penyalahgunaan Narkotika, Penyalah Guna tersebut wajib menjalani rehabilitasi medis dan rehabilitasi sosial." Berdasarkan ketentuan pasal di atas, maka terhadap pelaku penyalahgunaan narkotika dimungkinkan untuk dijatuhi sanksi tindakan rehabilitasi dan bukan sanksi pidana, sepanjang dapat dibuktikan bahwa dirinya adalah korban penyalahgunaan narkotika (Kaligis \& Associates, 2009).

Badan Narkotika Nasional merupakan Lembaga Negara Non Kementerian ditunjuk pemerintah sebagai leading sector dalam Upaya Pencegahan dan Pemberantasan, Penyalahgunaan dan Peredaran Gelap Narkoba. Salah satu tugasnya yaitu membentuk Tim Asesmen Terpadu untuk melakukan pemeriksaan tersangka narkotika. Tim Asesmen Terpadu yang terdiri dari tim dokter yang meliputi dokter dan psikolog, dan tim hukum yang terdiri dari unsur Polri, BNN, Kejaksaan, dan Kemenkumham

Tim hukum pada Tim Asesmen Terpadu bertugas melakukan analisis dalam kaitan peredaran gelap narkotika dan prekursor narkotika berkoordinasi dengan penyidik yang menangani perkara, sementara tim dokter bertugas melakukan asesmen dan analisis medis, psikososial serta merekomendasikan rencana terapi dan rehabilitasi penyalahguna narkotika. (BNN, 2018)
Tim dokter menggunakan formulir asesmen wajib lapor (Asesmen Severity Index ) dari kementerian kesehatan. Ruang lingkup pemeriksaan yang dilakukan oleh tim dokter yaitu pemeriksaan fisik, anamnesa dan asesmen komprehensif dan rapid tes urin sesuai indikasi.

Badan Narkotika nasional Provinsi Sumatera Barat merupakan perpanjangan tangan $\mathrm{BNN}$ di tingkat Provinsi telah melaksanakan Asesmen Terpadu. Dari tahun 2016 s.d 2018 tim asesmen terpadu mengeluarkan 175 rekomendasi. Dari jumlah tersebut 80 rekomendasi tidak di terima hakim sesuai rekomendasi yang telah di buat.

Berdasarkan wawancara dengan informan terdapat kendala dalam proses asesmen tersangka yaitu tim dokter kesulitan untuk mendiagnosis tersangka karena tim dokter menilai formulir asesmen wajib lapor (Asesmen Severity Index) belum lengkapnya anggota tim dokter, belum lcukupnya metode pemeriksaan untuk menegakkan diagnosis. Selain itu ada informan lann juga belum mengerti tentang maksud dan fungsi dari rekomendasi yang di buat oleh tim asesemen terpadu dalam memutuskan perkara tersangka penyalahguna narkotika.

Berdasarkan uraian di atas, Penulis tertarik untuk melakukan penelitian lebih lanjut Analisis Perumusan Rekomendasi Tim Asesmen Terpadu dan Penerimaan Hakim Badan Narkotika Nasional Provinsi Sumatera Barat. 


\section{METODE PENELITIAN Desain Penelitian}

Penelitian ini merupakan jenis penelitian kualitatif. Metode ini digunakan dengan tujuan memperoleh jawaban atau informasi mendalam tentang pendapat, persepsi dan perasaan seseorang (Lapau, 2013). Menurut (Moleong, 2017) penelitian kualitatif adalah penelitian yang bermaksud unutk memahami fenomena tentang apa yang dialami subjek penelitian misalnya perilaku, persepsi, motivasi, tindakan dan lainnya secara holistik dan dengan cara deskriptisi dalam bentuk katakata dan bahasa, pada suatu konteks khusus yang alamiah dan dengan memanfaatkan berbagai metode ilmiah.

Pada penelitian ini digunakan metode Framework Analysis yaitu suatu metode analisis dalam penelitian kualitatif yang memungkinkan peneliti dapat menjelaskan fenomena yang akan diteliti. Pada penelitian ini digunakan dua pendekatan yaitu pendekatan induktif yang didasarkan dari pengalaman informan dan pendekatan deduktif yang berasal dari literatur yang mendukung penelitian (Lacey A, 2009).

\section{Waktu dan Lokasi Penelitian}

Waktu penelitian dimulai dari bulan Mei s.d September 2019. Lokasi penelitian ini yaitu Badan Narkotika Nasional Provinsi Sumatera Barat dan Pengadilan Negeri Kota Padang

\section{Informan Penelitian}

Pemilihan informan yang dianggap mengetahui masalahnya secara lebih luas dan mendalam serta dapat dipercaya sebagai sumber data. Objek dalam penelitian kualitatif yaitu apa yang menjadi sasaran penelitian, dalam hal ini adalah rekomendasi tim asesmen terpadu.

Subjek atau informan dalam penelitian ini adalah subjek yang memahami informasi objek penelitian baik sebagai pelaku maupun lainnya atau dalam hal ini yang berkaitan dengan Asemen Terpadu. Atau disebut informan kunci, yaitu pihak-pihak yang tahu banyak mengenai Asemen Terpadu dan yang menerima hasil rekomendasi yaitu sehingga dapat memberikan data dan jawaban yang memadai saat wawancara Informan dalam penelitian ini adalah:
a. Lima orang tim dokter
b. Lima orang hakim

Tabel 1. Matrik Pengumpulan Data

\begin{tabular}{lcc}
\hline Tematik & $\begin{array}{c}\text { Tim } \\
\text { Dokter }\end{array}$ & Hakim \\
\hline
\end{tabular}

\begin{tabular}{lc}
\hline $\begin{array}{l}\text { Sumber } \\
\text { daya }\end{array}$ \\
manusia & $\mathrm{V}$ \\
Kebijakan & $\mathrm{V}$ \\
(SOP) & $\mathrm{V}$ \\
Sarana & $\mathrm{V}$ \\
Prasarana & $\mathrm{V}$ \\
Proses & $\mathrm{V}$ \\
pemeriksaan & $\mathrm{V}$ \\
Monitoring & \\
Penerimaan & $\mathrm{V}$ \\
rekomendasi & $\mathrm{V}$ \\
& \\
\hline Keterangan : & \\
WM : Wawancara Mendalam \\
\multicolumn{2}{l}{ Prosedur Pengambilan Dan } \\
Pengumpulan Data
\end{tabular}

Kegiatan yang dilakukan dalam penelitian ini secara garis besar adalah sebagai berikut:

1. Jenis Data

Jenis data yang dikumpulkan pada penelitian ini adalah data 
primer dan data sekunder

(Sugiyono, 2016).

2. Cara Pengumpulan Data

a. Wawancara semiterstruktur (semistructure interview)

Wawancara semiterstruktur dilakukan dengan tatap muka langsung dengan informan dengan menggunakan protokol wawancara (Moleong, 2017). Tujuan dari wawancara jenis ini adalah untuk menemukan permasalahan secara lebih terbuka dimana informan diminta pendapat dan ideidenya (Sugiyono, 2016). Pertanyaan dalam wawancara mengenai bagaimana proses asesmen yang dilakukan oleh dokter, kendala yang di hadapi, pengetahuan hakim tentang rekomendasi dari tim asesmen terpadu dan penyebab hakim menerima atau menolak rekomendasi.

b. Telaah dokumen

Telaah dokumen bertujuan untuk mengumpulkan dokumen terkait penelitian yang ditelaah secara mendalam sehingga bisa menjadi data penunjang penelitian. Dokumen yang ditelaah dalam penelitian ini rekap hasil asesmen, rekap nama tersangka, kesimpulan rekomendasi dan keputusan hakim.

\section{Instrumen Penelitian Kualitatif}

Instrumen penelitian atau alat pengumpul data yang digunakan adalah (Sugiyono, 2010):

1. Pedoman wawancara yaitu sederetan pertanyaan sehubungan dengan objek penelitian.
2. Buku catatan yang berfungsi untuk mencatat setiap hasil wawancara dan diskusi dengan informan sehubungan dengan objek penelitian.

3. Tape Recorder/ MP3/ MP4, berfungsi untuk merekam percakapan dengan sumber data (informan).

4. Kamera, berfungsi untuk mendokumentasikan kegiatan dalam penelitian yaitu pada saat wawancara mendalam.

\section{Pengolahan Data}

Pengolahan data kualitatif dilakukan dengan tahapan sebagai berikut (Sugiyono, 2010) :

a. Membuat transkip data

Membuat transkip data adalah memindahkan atau menyalin informasi dari bentuk pembicaraan lisan yang direkam dan berbagai informasi yang ada dalam catatan lapangan menjadi bentuk tulisan. Setiap informasi yang ditulis diberi sumber data agar dapat ditelusuri apabila informasi yang dirasa kurang lengkap.

b. Mereduksi data (data reduction)

Mereduksi data (data reduction) berarti merangkum, memilih hal-hal yang pokok, memfokuskan pada hal-hal yang penting, dicari tema dan polanya. Dengan demikian data yang telah direduksi akan memberikan gambaran yang jelas, dan mempermudah peneliti untuk melakukan pengumpulan data selanjutnya serta mencari data tambahan jika diperlukan. Semakin lama 
peneliti berada di lapangan maka jumlah data akan semakin banyak dan semakin kompleks. Oleh karena itu reduksi data perlu dilakukan sehingga data tidak bertumpuk dan agar tidak mempersulit analisis selanjutnya.

c. Menyajikan data (data display)

Setelah direduksi, maka langkah selanjutnya adalah menyiapkan data. Penyajian data diarahkan agar data hasil reduksi terorganisasikan, tersusun dalam pola hubungan sehingga makin mudah dipahami.Dalam penelitian kualitatif, penyajian data dapat dilakukan dalam bentuk uraian naratif, bagan, hubungan antar kategori, flowchart dan sejenisnya. Penyajian data dilakukan agar peneliti dapat menyusun data yang relevan sehingga informasi yang didapat disimpulkan dan memiliki makna tertentu untuk menjawab masalah penelitian.

d. Penarikan kesimpulan dan verifikasi (conclusion drawing/verification)

Kesimpulan awal yang dikemukakan masih bersifat sementara dan akan berubah bila tidak ditemukan buktibukti kuat yang mendukung pada tahap pengumpulan data berikutnya. Data display yang dikemukakan bila telah didukung oleh data-data yang mantap, maka dapat dijadikan kesimpulan yang kredibel. Dengan kata lain tahap ini merupakan tahap penarikan kesimpulan dari semua data yang telah diperoleh sebagai hasil dari penelitian.

\section{Analisis Data}

Semua data yang telah dikumpulkan dianalisis dengan pendekatan analisis isi, yaitu membandingkan dengan teori-teori yang ada dan tinjauan pustaka. Analisa dilakukan secara kualitatif dengan pembahasan secara deskriptif terhadap unsur proses dengan berbagai metode (Sugiyono 2010):

a. Triangulasi teknik atau metode yaitu dengan melakukan wawancara mendalam, observasi dan checklist. Untuk memperoleh kebenaran informasi yang handal dan gambaran yang utuh mengenai informasi tertentu, peneliti bisa menggunakan metode wawancara dan observasi atau pengamatan untuk mengecek kebenarannya.

b. Triangulasi sumber yaitu dengan crosscheck dengan sumber data lain, membandingkan dan melakukan kontras data, serta menggunakan kategori informan yang berbeda. Maksudnya untuk menggali kebenaran informasi tertentu melalui berbagai metode dan sumber perolehan data. Misalnya, selain melalui wawancara dan obse;lorvasi, peneliti bisa menggunakan observasi terlibat (participant observation), dokumen tertulis, arsip, dokumen sejarah, catatan resmi, dan gambar atau foto. Masingmasing itu akan 
menghasilkan bukti atau data yang berbeda yang akan memberikan pandangan berbeda pula mengenai fenomena yang diteliti.

\section{HASIL DAN PEMBAHASAN}

\section{Sumber Daya Manusia (SDM)}

Berdasarkan hasil penelitian didapatkan komposisi tim dokter belum terpenuhi. Menurut Permenkes Nomor 50 tahun 2015 anggota tim dokter terdiri dari dokter spesialis kedokteran jiwa, dokter spesialis forensik, dokter, dan psikolog yang berasal dari fasilitas rehabilitasi medis/IPWL, organisasi profesi, kepolisian dan Badan Narkotika Nasional yang berjumlah paling sedikit dua orang. Dalam hal di daerah tidak ada dokter spesialis kedokteran jiwa, dokter spesialis forensik dan psikolog, maka Tim Dokter adalah dokter yang terlatih di bidang gangguan penggunaan NAPZA yang dalam implementasi asesmen dapat dibantu oleh tenaga kesehatan lain yang terlatih di bidang asesmen gangguan penggunaan NAPZA. Ketua Tim Dokter adalah dokter spesialis kedokteran jiwa atau dokter spesialis forensik. Ketua Tim Dokter adalah dokter yang terlatih di bidang gangguan penggunaan NAPZA.

\section{a. Pengetahuan hakim}

Berdasarkan hasil penelitian di dapatkan hakim kurang mengerti tentang proses asesmen terpadu.

\section{Sarana dan Prasarana}

\section{a. Kebijakan / Standar Operasional Pelayanan (SOP)}

Badan Narkotika Nasional Provinsi Sumatera Barat dalam pelaksanaan asesmen terpadu menggunakan standar yang tertuang dalam Standar Operasional Prosedur (SOP). Pada Pengadilan Negeri Kota Padang pelaksanaan putusan pada tersangka penyalahguna narkotika yang melewati assmen terpadu masih belum sesuai dengan harapan. Dari penelitian ditemukan penyebab dari masalah tersebut yaitu karena masih terdapat kekurangan SOP/ kebijakan yaitu mengenai pengaturan pelaksanaan putusan tersangka penyalahguna narkotika dengan melewati asesmen terpadu. Selain itu SOP tentang kelengkapan berkas untuk tersangka yang memang memenuhi syarat untuk di laksanakan asesmen terpadu juga tidak ada. SOP yang sudah ada juga belum optimal di laksanakan yaitu SOP tentang jumlah tenaga tim dokter yang terlibat dalam asesmen terpadu.

Berdasarkan hasil penelitian diatas peneliti menyarankan agar SOP yang kurang segera bisa dibuat, SOP yang lama direvisi sesuai dengan kebutuhan pelayanan. Setelah SOP baru terbit maka dibutuhkan sosialisasi kepada tim dokter dan hakim. Monitoring dan evaluasi pelaksanaan SOP secara berkala juga perlu dilakukan agar pelaksanaan asesmen terpadu lebih terarah sehingga dapat mencapai tujuan.

\section{b. Alat Pemeriksaan}

Dari hasil penelitian ini peneliti menyimpulkan terdapat kekurangan dalam sarana untuk melakukan pemeriksaan terhadap tersangka. Saat ini alat yang di gunakan untuk pemeriksaan yaitu formulir asesmen wajib lapor dan pemeriksaan urine dengan menggunakan alat tes urine. Menurut Permenkes Nomor 50 tahun 2015 Tim Dokter bekerja secara 
profesional, sesuai dengan kompetensi yang dimilikinya dan memegang kode etik profesi. Tim Dokter bertugas melakukan asesmen medis dan psikososial serta merekomendasi rencana terapi dan rehabilitasi. Asesmen medis dan psikososial serta merekomendasi rencana terapi dan rehabilitasi ditujukan untuk menentukan derajat keparahan masalah medis, dukungan hidup, penggunaan Napza, riwayat legal, riwayat keluarga dan sosial, serta status psikiatrik, menentukan diagnosa kerja sesuai pedoman diagnosa (PPDGJ III atau ICD-X) dan merekomendasi rencana terapi dan rehabilitasi terhadap pengguna narkotik sesuai pedoman yang berlaku. Asesmen medis dan psikososial Tim Dokter terhadap tersangka/terpidana meliputi pemeriksaan fisik, anamnesa dan asesmen komprehensif menggunakan formulir asesmen wajib lapor/rehabilitasi medis yang diterbitkan Kementerian Kesehatan; dan rapid tes urin sesuai indikasi.

Dalam hal diperlukan asesmen lebih lanjut dapat dilakukan pemeriksaan psikiatrik lebih intensif sesuai indikasi, evaluasi psikologik bila diperlukan, rapid tes urin sesuai indikasi dan bilamana diperlukan dan pemeriksaan penunjang diagnostik lainnya sesuai indikasi. Guna memperoleh data yang relatif akurat dan mengoptimalkan hasil asesmen, maka proses asesmen Tim Dokter perlu dilakukan dalam ruangan yang dapat menjaga privasi dan tidak dihadiri oleh pihak ketiga, baik keluarga, profesional lain ataupun penegak hukum, kecuali pada kasuskasus khusus.

Kekurangan sarana tesebut bisa jadi penyebab langsung tidak di terimanya rekomendasi tim dokter asesmen terpadu. Solusi pemecahan masalah bisa dilakukan dengan melakukan rapat dengan pimpinan mengenai kebutuhan pemeriksaan lanjutan khusus untuk tersangka. Membuat sistematik dan alur pemeriksaan tersangka serta membuat rencana anggaran biaya untuk pemeriksaan tambahan tersebut.

\section{Proses}

Berdasarkan hasil penelitian proses pemeriksaan tersangka yaitu Peroses pemeriksaan dilakukan dengan baik namun hasil pemeriksaan menjadi kurang lengkap karena proses pemeriksaan tidak cukup. Kekurangan tenaga menyebabkan pemeriksaan dilakukan oleh satu orang. Pada pemeriksaan, tersangka berada pada fase penolakan dimana mereka merasa tidak sakit dan tidak perlu di obati. Fase ini dinamakan dengan fase prekontempelasi. (Prochaska, DiClemente.)

Fase prekontempelasi di tandai ketika seseorang tidak memiliki niat untuk mengganti perilakunya. Individu yang berada di tahap ini bisa saja sudah mendapat informasi atau belum mendapat informasi tentang konsekuensi perilakunya. Atau dia sudah pernah mencoba untuk merubahnya dan menjadi tidak peduli tentang hal tersebut. (Prochaska, DiClemente.1970).

Pemeriksaan spesifik dibutuhkan untuk menilai kemampuan kognitif, kepribadian, tes intelejensi, tes mengungkapka kebutuhan, tes mengukur kejujuran. Tes tersebut yaitu IST, EPPS, EYSENCK.

\section{Secara}

patofisiologis pengaruh zat terjadi di otak yaitu jaras reward (reward pathway). Jaras ini melibatkan beberapa bagian otak, antara lain: ventral tegmental area 
(VTA), nucleus accumbens (NAc), dan prefrontal cortex (PFC). Saat teraktivasi oleh suatu rangsang yang menyenangkan (rewarding stimulus). Perasaan senang/nikmat muncul akibat adanya pelepasan neurotransmiter dopamin ke Nac pada reward system. Area lain di otak merekam situasi dan lingkungan yang berkaitan dengan perasaan menyenangkan ini ke dalam memori. Memori ini, disebut conditioned associations, seringkali menyebabkan craving (menagih) zat saat pengguna zat berhadapan dengan orang, tempat, atau benda yang berkaitan denga penggunaan zatnya. Hal ini dapat mengarahkan pengguna zat untuk mencari zat lagi. (Kaplan \& Sadock's, 2015).

Paparan berulang terhadap peningkatan dosis zat mengubah fungsi otak sehingga fungsimenjadi normal saat terdapat zat dan tidak normal saat tak menggunakan zat. Dua dampakklinis yang penting dari perubahan ini adalah toleransi (kebutuhan untuk menggunakan dosislebih tinggi untuk mencapai efek zat yang sama) dan juga ketergantungan

(dependence), kecenderungan untuk mengalami gejala putus zat. Gejala putus zat muncul hanya bila pasien telah mengalami toleransi (American Psychiatric Association, 2013).

Pada keadan tersebut, organ sistemik bisa terjadi gangguan. Pemeriksaan lanjutan sebaiknya dilakukan untuk menilai fungsi otak dan organ target lain yang dipengaruhi oleh penggunaan zat narkotika. Pemeriksaan tersbut yaitu pemeriksaan fungsi otak, pemeriksan darah, dan pemeriksaan imagine yang lain.

Pada waktu pemeriksaan tersangka oleh tim hukum dilakukan dalam satu hari. Pendeknya waktu pemeriksaan dipengaruhi oleh lamanya peyidik mengajukan permohonan asesmen terpadu. Waktu pengerjaan asesmen dan pemeriksaan sebagaimana dimaksud angka 2 di atas minimal adalah 1 (satu) x 24 jam dan maksimal adalah 2 (dua) x 24 jam sejak diterimanya berkas permohonan kepada Tim Asesmen Terpadu. (Permenkes, 2015)

Selain itu anggaran dari tiap Polda atau Polres untuk pengantaran tersangka hanya 1 (satu) hari. Hal ini berakibat pada pendeknya waktu pemeriksaan. Jika pemeriksaan lengkap dilakukan oleh tim dokter, waktu kontak dengan tersangka lebih dari $2 \times 24$ jam.

$$
\text { Berdasarkan triangulasi }
$$

Monitoring waktu pemeriksaan tersangka dapat disimpulkan bahwa Belum optimalnya monitoring oleh Badan Narkotika Nasional Provinsi Sumatera Barat. Monitoring dan evaluasi harus dilakukan ke instansi/satuan kerja yang terlibat dalam asesmen terpadu yaitu Badan Narkotika Nasional, Kejaksaan Negeri, dan Polda. Selain monitoring dan evaluasi eksternal, monitoring internal sangat di perlukan untuk penyempurnaan program. Melalui evaluasi kekurangan dan kelebihan di ketahui. Kegiatan monitoring dan evakuasi bisa dengan cara rapat koordianasi, bimbingan teknis, rapat kerja.

\section{Penerimaan Hakim}

Dari hasil penelitian mengenai asesmen terpadu bahwa Hakim belum paham tentang pengertian asesmen terpadu. Hakim belum mengerti secara komprehensif mengenai alur asesmen terpadu dari proses pengajuan sampai hasil rekomendasi.

Sikap manusia terhadap suatu objek perlu diungkap. Hal ini dimaksudkan untuk mengetahui pengetahuan seseorang tentang suatu objek, perasaan seseorang dalam 
menanggapi objek, serta kecenderungan seseorang untuk berbuat terhadap objek. Sikap adalah sekelompok keyakinan dan perasaan yang melekat tentang objek tertentu dan kecenderungan untuk bertindak terhadap objek tersebut dengan cara tertentu. Oleh sebab itu, sikap selalu bermakna bila dihadapkan kepada objek tertentu (dalam penelitian ini objek tersebut adalah mata pelajaran Bahasa Indonesia).

Sikap sebagai cerminan dari kemampuan penalaran afektif yang dapat ditinjau dari tiga komponen dasar perkembangan psikologi yaitu: kognisi, afeksi dan konasi. Komponen kognisi meliputi persepsi, kepercayaan, dan pengetahuan yang dimiliki individu. Kompenen afeksi merupakan perasaan individu terhadap objek sikap dan perasaan yang menyangkut masalah emosional. Komponen konasi merupakan tendensi atau kecenderungan bertindak atau bereaksi terhadap sesuatu dengan cara-cara tertentu. (Nadhifah, 2012)

$$
\text { Menurut Walgito (dalam }
$$

Puspasari, 2010), bahwa sikap mengandung tiga komponen yang membentuk struktur sikap, yaitu: kognitif (konseptual), afektif (emosional), dan konatif (perilaku atau action component). Komponen kognitif merupakan komponen yang berkaitan dengan keyakinan terhadap hal-hal yang berhubungan dengan persepsi terhadap objek. Komponen afektif merupakan komponen yang berhubungan dengan rasa senang atau tidak senang terhadap objek sikap. Sedangkan, komponen konatif merupakan komponen yang berhubungan dengan kecenderungan bertindak terhadap objek sikap. (Puspasari, 2010)

\author{
Dalam memutus perkara, \\ hakim wajib memperhatikan \\ ketentuan sebagaimana dimaksud \\ dalam Pasal 54, Pasal 55, dan Pasal \\ 103. (UU No.35 tahun 2009).
}

\section{B. Keterbatasan Penelitian}

Keterbatasan peneliti dalam penelitian ini adalah penelitian ini hanya bersifat deskriptif dengan memberikan gambaran terhadap penyebab tidak diterimanya rekomendasi tim asesmen terpadu Badan Narkotika Nasional Provinsi Sumatera Barat. Penelitian ini tidak dilanjutkan dengan menganalisa ke bagian keuangan tentang proses penganggaran dari asesme terpadu. Penelitian ini juga tidak melanjutkan ke proses pemberkasan dan pemeriksaa oleh penyidik atau jaksa. Penelitian ini ini bisa menjadi bahan penelitian selanjutnya dengan menganalisis pemeriksaan yang dilakukan oleh penyidik dan jaksa dalam mengajukan permohonan asesme terpadu.

$$
\text { Berdasarkan hasil penelitian }
$$
yang didapatkan, peneliti menyarankan agar Badan Narkotika Nasional Provinsi Sumatera Barat untuk dapat melaksanakan POA (Plan Of Action) yang dijelaskan pada tabel berikut ini :

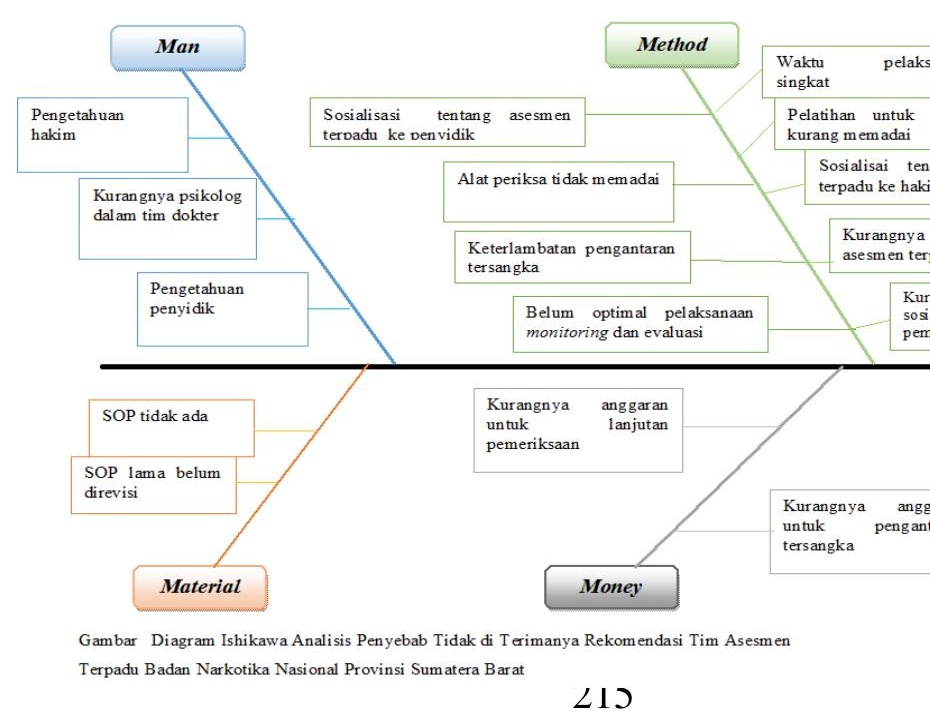




\section{KESIMPULAN}

Penelitian yang telah dilakukan pada Badan Narkotika Nasional Provinsi Sumatera Barat mengenai penyebab tidak diterimanya rekomendasi tim asesmen terpadu akibat kurangnya faktor input, proses dan output. Di sisi outcome hakim belum mengerti tentang asesmen terpadu mulai dari permohonan sampai pemberian rekomendasi.

1. Sumber Daya Manusia

a. Manajemen sumber daya manusia (SDM) yaitu:

1) Perlunya penambahan tenaga untuk melaksanakan TAT

2) Belum terpenuhinya pelatihan dan peningkatan kemampuan bagi tim dokter

2. Sarana dan Prasarana

a. Kebijakan / SOP yang tidak di terimanya rekomendasi tim asesmen terpadu adalah:

1) SOP yang mengatur tentang penjatuhan hukuman tersangka narkotika

2) Belum adanya SOP mengenai kelengkapan berkas tersangka narkotika

3. Sarana yang mempengaruhi tidak di terimanya rekomendasi tim asesmen terpadu adalah :

a. Pemeriksaan lanjutan untuk menilai efek penggunaan narkotika terhadap organ tubuh belum ada

b. Pemeriksaan untuk penilaian perilaku, fungsi kognitif, emosi, dan pemeriksaan psikologi yang di butuhkan belum ada.

3. Proses Pemeriksaan

a. Pemeriksaan tersangka

1) Proses pemeriksaan dilakukan dengan baik namun hasil pemeriksaan menjadi kurang lengkap karena proses pemeriksaan tidak cukup

2) Kekurangan tenaga menyebabkan pemeriksaan dilakukan hanya oleh dokter umum.

3) Tersangka berada pada fase penolakan dimana mereka merasa tidak sakit dan perlu di obati

b. Waktu

pemeriksaan tersangka

1) Kurang patuhnya penyidik dalam mengajukan asesemen terpadu sehinggan waktu pemeriksaan tersangka menjadi pendek

2) Tidak ada anggaran untuk menghadirkan kembali

c. Monitoring dan Evaluasi

Belum optimalnya monitoring oleh Badan 
Narkotika Nasional Provinsi Sumatera Barat dengan cara rakor, raker, bimtek dan coffe morning.

4. Outcome (Harapan)

Hakim belum paham tentang pengertian asesmen terpadu. Hakim belum mengerti secara komprehensif mengenai alur asesmen terpadu dari proses pengajuan sampai hasil rekomendasi.

\section{UCAPAN TERIMA KASIH}

Syukur Alhamdulillah penulis ucapkan kehadirat Allah SWT, yang telah melimpahkan rahmat dan karuniaNya sehingga penulis dapat menyelesaikan proposal tesis ini

Selam proses pengerjaan proposal tesis ini penulis banyak mendapatkan bantuan, bimbingan dan arahan yang bermanfaat dari berbagai pihak, untuk itu penulis ingin menyampaikan rasa terima kasih kepada :

1. Bapak Dr. dr. Wirsma Arif Harahap, SpB (K) Onk selaku dekan Fakultas Kedokteran Universitas Andalas Padang.

2. Ibu Dr. dr. Rima Semiarty, MARS selaku selaku Ketua Program Studi Pascasarjana Kesehatan Masyarakat Universitas Andalas Padang.

3. Bapak dr. Hardisman, MHID, Dr.PH selaku pembimbing I yang telah meluangkan waktu, tenaga dan pikiran untuk membimbing, dan memberikan saran yang sangat berguna dalam proses pembuatan tesis ini.

4. Ibu Dr. dr. Rika Susanti, Sp.F selaku pembimbing II yang juga telah meluangkan waktu, tenaga dan pikiran untuk membimbing, dan memberikan saran yang sangat berguna dalam proses pembuatan tesis ini.

5. Bapak dan Ibu Dosen Program Pascasarjana Kesehatan Masyarakat dan staf Pascasarjana Kesehatan Masyarakat Universitas Andalas Padang.

6. Keluarga, sahabat, serta temanteman Program Pascasarjana Kesehatan Masyarakat Universitas Andalas angkatan 2017 atas kerjasama serta dukungannya.

7. Teman-teman Dokter BNN seluruh Indonesia dan BNN Prov Sumbar.

Akhir kata, semoga Allah SWT membalas segala kebaikan semua pihak yang telah membantu. Penulis berharap semoga penelitian proposal tesis ini diterima dan bermanfaat bagi perkembangan ilmu pengetahun ke depannya.

\section{REFERENSI}

Abdulkadir, M. 2004. Hukum dan Penelitan Hukum. PT. Citra Aditya Bakti. Bandung

Alatas, HH. 2001. Penanggulangan

Korban

Narkoba:

Meningkatkan Peran

Keluarga dan Lingkungan.

Fakultas Kedokteran

Universitas Indonesia.

Jakarta.

American Psychiatric Association. 2013. Diagnostic and Statistical Manual of Mental Disorders, Fifth Edition. Arlington, VA, American Psychiatric Association.

Arief, MD. dan Elisatris Gultom. 2007. Urgensi Perlindungan Korban Kejahatan. PT. Raja Grafindo Persada. Jakarta. 
Asya, F. 2009. Narkotika dan Psikotropika. Asa Mandiri. Jakarta.

Atmasasmita, R. 1992. Tindak Pidana, Teori dan Kapita Selekta Kriminologi, PT. Eresco. Bandung.

Badan Narkotika Nasional. 2007. Pencegahaan Penyalahgunan Narkotika Sejak Usia Dini, BNN. Jakarta.

Gosita, A. 1989. Masalah Perlindungan Anak. Akademi Presindo. Jakarta.

Hawari, D. 2003. Penyalahgunaan dan Ketergantungan NAZA (Narkotika, Alkohol dan Zat Adiktif). Gaya Baru. Jakarta.

Kep Menkes No. 486/MENKES/SK/IV/2007 tentang Kebijakan \& Rencana Strategi Penanggulangan Penyalahgunaan Narkotika

Lapau, B., 2013. Metode Penelitian Kesehatan. 2 Ed. Jakarta: Yayasan Pustaka Obor Indonesia.

Marnat, GG. 2003. Handbook of Psychological Assesment. New York: Van Nostrand Reinhold Company. Inc. 638.

Mardani, 2008. Penyalahgunaan Narkoba Dalam Perspektif Hukum Islam dan

Hukum Pidana Nasional. Rajagrafindo Pustaka. Jakarta.

McLellan, TA. Asesment Severity Index. 1981 dari Universitas Pensylvania, Amerika Serikat.

Miller, PM. Principles of Addiction. 2013. Comprehensive Addictive Behaviors and Disorders. Volume 1. Elsevier. San Diego, California.
Nasution, Z. 2007. Memilih Lingkungan Bebas Narkoba. Badan Narkotika Nasional. Jakarta.

Partodiharjo, S. 2007. Kenali Narkoba dan Musuhi Penyalahgunaannya. Esensi. Jakarta.

Pedoman Penggolongan dan Diagnosis Gangguan Jiwa di Indonesia III. 1993 Departemen Kesehatan RI

Peraturan Kepala BNN Nomor 13 Tahun 2014 tentang Tata Cara Penanganan Tersangka dan/atau Terdakwa Pecandu narkotika dan Korban Penyalahguna Narkotika ke dalam Lembaga Rehabilitasi

Peraturan Bersama Ketua Mahkamah Agung Republik Indonesia, Menteri Hukum dan Hak Asasi Manusia Repulik Indonesia, Menteri Kesehatan Republik Indonesia, Menteri Sosial Republik Indonesia, Jaksa Agung Republik Indonesia, Kepala Kepolisian Negara Republik Indonesia, Kepala Badan Narkotika Nasional Republik Indonesia Tentang Penanganan Pecandu Narkotika dan Korban Penyalahgunaan Narkotika ke dalam Lembaga Rehabilitasi.

Peraturan Menteri Kesehatan Nomor 50 Tahun 2015 tentang Petunjuk Teknis Wajib Lapor Pecandu Narkotika

Peraturan Menteri Kesehatan Nomor 80 Tahun 2014 tentang Petunjuk Teknis Pelaksanaan Rehabilitasi Medis Bagi Pecandu, Penyalahguna dan Korban Penyalahguna yang Sedang dalam Proses Penyidikan, Penuntutan, dan Persidangan atau Telah 
Mendapatkan

Penetapan/Putusan Pegadilan

Prochaska, James O., \& Velicer, Wayne F. (1997). The Transtheoretical Model of Health Behavior Change. American Journal of Health Promotion

Prasetyo, T \& Barakatullah, AH. 2005. Politik Hukum Pidana

Kajian

Kebijakan

Kriminalisasi dan

Deskriminasi. Pustaka

Belajar. Yogyakarta.

Riduwan. 2012. Skala Pengukuran

Variabel-Variabel Penelitian.

Bandung: Alfabeta.

Sasangka, H. 2003. Narkotika dan

Psikotropika Dalam Hukum

Pidana. Mandar Maju.

Bandung.

Sadock, BJ, Sadock, VA \& Ruiz, P.

2015.

Behavioral

Sciences/Clinical Psychiatry. Eleventh Edition. Wolters Kluwer. Philadelphia

Strain, EC \& Ruiz, P. 2011. Substance Abuse $A$ Comprehensive Textbook, Fifth Edition. Lippincott Williams \& Wilkins. Philadelphia, PA.

Stahl, SM. 2013. Neuroscientific

Basis and Practical Application. Fourth edition. Cambridge University Press, New York.

Sugiyono. 2010. Memahami Penelitian Kualitatif.

Bandung: Alfabeta.

Sugiyono. 2013. Metode Penelitian

Pendidikan Pendekatan

Kuantitatif, Kualitatif, dan

$R \& D$. Bandung: Alfabeta.

Supramono, G. 2004. Hukum Narkoba Indonesia.

Djambatan. Jakarta.
Supramono, Gatot. 2004. Hukum

Narkoba Indonesia.

Djambatan. Jakarta.

Supriyadi. 2014. Statistik Kesehatan.

Purwokerto: Salemba Medika

Suyono, Y.P. Joko. 1980. Masalah

Narkotika dan Bahan Sejenisnya.

Yayasan

Kanisius. Yogyakarta.

Undang-Undang Nomor 35 Tahun 2009 Tentang Narkotika

Undang-Undang Nomor 36 Tahun

2009 tentang Kesehatan

Yatim, M 1991. Keluarga dan Narkotika (Tinjauan Sosial Psikologis). Arcan. Jakarta.

Walgito, Bimo (2008). Psikologi Sosial

Waluyo, B. 2011. Viktimologi, Perlindungan Saksi dan Korban.

Sinar

Grafika. Jakarta. 